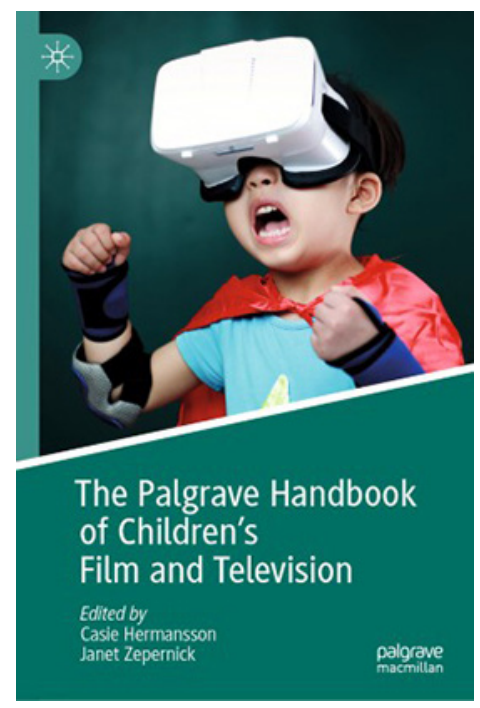

KUNNIANHIMOINEN ARTIKKELIKOKOELMA PYRKII LAAJENTAMAAN KÄSITYSTÄ LASTENELOKUVASTA

Casie Hermansson \& Janet Zepernick (toim.) (2019) The Palgrave Handbook of Children's Film and Television. Palgrave Macmillan. $592 \mathrm{~s}$.
Lastenelokuva on usein jäänyt aikuisille suunnatun elokuvan jalkoihin niin elokuvakulttuurisessa arvostuksessa mitattuna kuin akateemisen tutkimuksen kentillä. Lastenelokuvaa käsittelevä tutkimus on lisääntynyt ja monipuolistunut viime vuosina. Tästä hyvä esimerkki on mittava artikkelikokoelma The Palgrave Handbook of Children's Film and Television, jonka kunnianhimoisena tavoitteena on valottaa aihettaan sekä maantieteellisesti että temaattisesti hyvin laajasta ja aiempaa moninaisemmasta näkökulmasta. Teos käsittelee lasten mediakulttuuria elokuvan ja television lähtökohdista käsin, mutta ulottaa analyysin myös muun muassa algoritmien ohjaamaan lasten mediamaisemaan sekä lasten ja nuorten omaan mediatuotantoon.

Teos on harvinainen esitys lastenelokuvasta sikälikin, että se pyristelee irti euro- ja angloamerikkalaisuuskeskeisyydestä. Onkin kiinnostavaa lukea esimerkiksi siitä, miten lapsuus rakentuu iranilaisessa lastenelokuvassa ja millaisia käsityksiä lapsuudesta ja perheestä iranilainen tai vaikkapa kiinalainen lastenelokuva kierrättää ja vahvistaa. Kirjassa kysytään myös muun muassa, millainen asema lastenelokuvalla on ollut Intiassa tai millaista rajanvetoa filippiiniläisessä lastenelokuvassa tehdään lokaalin ja globaalin välillä. Tosin tarve ikään kuin puolustella ja perustella lastenelokuvan tutkimusta nousee ajoittain esille vähintäänkin rivien välissä. Lastenelokuvia pyritään esimerkiksi helposti legitimoimaan aikuisille relevanttien tulkintamallien kautta. Esimerkiksi Amir Ali Nojoumianin artikkelissa
"Constructing Childhood in Modern Iranian Children's Cinema: A Cultural History" tämä näkyy lapsihenkilöiden tulkitsemisessa modernin Iranin metaforana.

Mitä tulee lastenelokuvan määrittelyyn, artikkelikokoelman toimittajat myöntävät johdannossa auliisti olevansa vaativan tehtävän edessä. Lastenelokuvan määritelmiä kuitenkin eritellään kattavasti ja lopulta päädytään Noel Brownin määritelmään, joka pohjaa lapseen oletettuna katsojana. Määritelmä ei tosin läpäise kaikkia kirjan artikkeleita, sillä osassa niistä ei tehdä eroa lapsille tehdyn elokuvan ja lapsihenkilöistä kertovan elokuvan välille. Raja toki onkin usein häilyvä, mutta selkeästi aikuisyleisölle suunnattujen elokuvien poisrajaaminen olisi terävöittänyt kirjan fokusta. Näitä käsittelevissä artikkeleissa huomio siirtyy liikaa sivuun lapsille suunnatun sisällön ja lapsikatsojuuden näkökulmasta. Esimerkiksi Sonia Ghalianin artikkelissa "In Search of the Elusive Bird: Childhood from the Margins in Fandry" tarkastellaan elokuvaa, joka kommentoi lapsuuden kuvauksella intialaisen yhteiskunnan epätasa-arvoa ja vastustaa kastikäytäntöä. Tässä keskushenkilönä olevaa lasta käytetään aikuisyleisön myötätunnon herättäjänä. Evy Varsamopouloun artikkelissa "Entering the Labyrinth of Ethics in Guillermo del Toro's El laberinto del fauno" aikuisille suunnattua elokuvaa lähestytään filosofian ja (pahuuden) etiikan näkökulmasta.

Useammassa artikkelissa myös vähintään vihjataan, että lastenelokuvaa tulisi kehittää taiteellisesti kunnianhimoisempaan suuntaan. 
Epäselväksi kuitenkin jää, millä tavalla ja ketä varten. Tällaisissa vaateissa jää helposti huomioimatta lasten ja aikuisten erilaiset esteettisen arvottamisen tavat. Kiinnostavampaa olisikin kysyä, miten lastenelokuvaa voisi kehittää lapsilähtöisesti.

Toisaalta kirja myös etsii ja haastaa lastenelokuvan rajoja tervetulleella tavalla. Esimerkiksi artikkelissaan "Change and Continuity in Contemporary Children's Cinema" Noel Brown kysyy, millaisia aiheita lastenelokuva voi käsitellä. Käyttäen esimerkkinä elokuvaa Elämäni kesäkurpitsana (Ma vie de Courgette, Ranska $\mathcal{E}$ Sveitsi 2016) hän toteaa, että myös "aikuisia" teemoja voi käsitellä lastenelokuvassa lapsiyleisöä kunnioittaen. Ajatuksessa ei toki ole mitään uutta, mutta edelleen on suhteellisen harvinaista nähdä lastenelokuva, jossa käsiteltäisiin lapsilähtöisesti elämän nurjia puolia. Yksi kirjan ehdottomista ansioista onkin lastenelokuvan moninaisuuden ja lajityyppien kirjon esiin tuominen. Paikkansa kirjassa on muun muassa lasten kauhuelokuvalla.

Lasten omaan osallisuuteen ja toimijuuteen päästään parhaiten kiinni elokuvanlukutaitoa ja elokuvakasvatusta käsittelevässä osassa. Enemmistö tämän osuuden artikkeleista lähestyy lasten ja nuorten toimijuutta omien mediatuotantojen tekijöinä, mikä on tervetullutta, mutta myös aktiivisen katsojuuden tarkastelu elokuvakasvatuksen näkökulmasta olisi tarpeen. Erityisesti, koska kirjassa pyritään haastamaan käsityksiä lasten mediankulutuksesta passivoivana toimintana. Osiossa ollaan joka tapauksessa lähimpänä käytäntöä, ja artikkelit tarjoavat konkreettista pedagogista tukea elokuvanlukutaidon ja elokuvakasvatuksen kehittämiseen. Laajemman mediakasvatuksellisen keskustelun näkökulmasta kirja sisältää kuitenkin joitakin erikoisia valintoja ja näkökulmia. Esimerkiksi kiistanalaista termiä diginatiivi viljellään muutamaan otteeseen ja joissakin artikkeleissa viitataan ruutuaikatutkimukseen tavalla, joka ei vastaa viimeisintä mediakasvatuksen kentän näkemystä.

Elokuvakasvatusosuudessa laajasti käsiteltyyn lukutaitonäkökulmaan linkittyy myös adaptaatiokysymyksiä käsittelevä osuus. Adaptaatiotutkimus onkin luonteva lähestymistapa lastenelokuvatutkimukselle, onhan erittäin merkittävä osa lastenelokuvista kirjallisuus- tai satuadaptaatioita. Lisäksi kirjan ja elokuvan suhde on perinteisesti ollut esillä myös kasvatuksellisesta näkökulmasta. Kirjan artikkelit lähestyvät aihetta kiitettävän monipuolisesti nostaen esiin muun muassa revisionistiset uudelleen tulkinnat. Teemaa käsitellään tuoreesta näkökulmasta myös Siobhan O'Flynnin Disneyn transmediaalista tarinauniversumia käsittelevässä artikkelissa "Data Science, Disney, and the Future of Children's Entertainment", jossa nostetaan esiin personoituun sisältöön liittyvät yksityisyyden suojan kysymykset, ja joka siten sekin liittyy osaksi laajempaa mediakasvatuksellista keskustelua.

Lasten ja nuorten kuluttamien mediasisältöjen representaatioihin on kiinnitetty huomiota jo pitkään, ja teema nousee esiin myös tässä teoksessa. Näiltä osin kirja myös kiinnittyy edelleen ajankohtaiseen keskusteluun siitä, kuka näkyy ja kenen ääni kuuluu. Becky Parry saa aiheesta irti kiinnostavia näkökulmia ja esittää ratkaisuehdotuksia tyttöyden representaatioiden monipuolistamiseksi artikkelissa "Finding the Hidden Child: The (Im)Possibility of Children's Films". Hän kysyy, miksi monet tyttöjen ja naisten biologiaan liittyvät asiat, kuten kuukautiset, rajataan ulos lapsille sopivista aiheista. Perry huomauttaa, että naisten tekemien elokuvien lisääntyminen tuo esiin naisten ja tyttöjen kokemuksia, riisuu niitä tabuista ja monipuolistaa representaatioita.

Toinen sukupuolten representaatioita käsittelevä artikkeli, Dafna Lemishin ja Nelly Eliasin "Perpetuating Gender Stereotypes from Birth: Analysis of TV Programs for Viewers in Diapers", taas ei saa pintatasoa kummempaa irti taaperoille suunnatun tv-tarjonnan sukupuolirepresentaatioiden analyysistä. Sinällään on toki ansiokasta, että yleensä aika vähälle huomiolle jäävä pienten lasten mediamaailma on mukana kirjan artikkeleissa. "Power, Prejudice, Predators, and Pets: Representation in Animated Animal Films"-artikkelissa ruoditaan pinnalta katsottuna ennakkoluuloja vastaan taistelevaa, mutta pohjimmiltaan vahingollisia stereotyyppejä ja rasistista virettä viljelevää Zootropolis - eläinten kaupunki -elokuvaa (Zootopia, USA 2016). Lähestymistavan perustelu on yllätyksetön: lastenelokuvan viestien tutkiminen on tärkeää, koska se kuten muukin lastenkulttuuri näyttelee avainroolia lasten maailmankuvien muovaamisessa. Jäin 
kuitenkin kaipaamaan tässä yhteydessä lapsikatsojan näkemistä aktiivisena toimijana, joka kykenee haastamaan elokuvan tarjoamat merkitykset ja tulkitsemaan niitä myös aivan omista, todennäköisesti aikuiselle yllättävistä näkökulmista.

Artikkelikokoelmille tyypillisestä epätasaisuudesta huolimatta kirjan ehdoton ansio on, että kokonaisuudessaan se ottaa lastenelokuvan vakavasti, myös taiteenlajina ja luovan toiminnan tuloksena. Teos todistaa lastenelokuvan ja lasten mediakulttuurin olevan tasavertainen tutkimuskohde ja ansaitsevan akateemisen huomion niin sisältöjen, tuotannon kuin yleisöjen näkökulmasta. Kirja on askel kohti maailmaa, jossa lastenelokuvaa arvostetaan ja arvotetaan täysivaltaisena elokuvakulttuurin osana.

\section{Marjo Kovanen}

erityisasiantuntija, Koulukino 